JOEAI (Journal of Education and Instruction)

Volume 1, Nomor 2, Desember 2018

e-ISSN : 2614-8617

p-ISSN : 2620-7346

DOI: https://doi.org/10.31539/joeai.v1i2.463

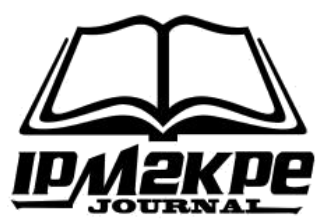

\title{
PENGARUH KESEJAHTERAAN GURU KOMITE TERHADAP SEMANGAT MENGAJAR GURU
}

\author{
Marsel Nande ${ }^{1}$, Sayful Amrin ${ }^{2}$ \\ Universitas Flores ${ }^{1,2}$ \\ marsel2018@gmail.com ${ }^{1}$
}

\begin{abstract}
ABSTRAK
Penelitian ini bertujuan untuk mengetahui pengaruh kesejahteraan guru komite terhadap semangat mengajar guru SMA negeri se-kecamatan Kota Komba Kabupaten Manggarai Timur Nusa Tenggara Timur. Jenis penelitian yang digunakan yaitu penelitian kuantitatif yang menekankan analisis pada data numerikal (angka) yang diperoleh dengan metode statistik dengan variabel bebasnya adalah kesejahteraan guru dan variabel terikatnya adalah semangat mengajar. Sampel adalah 25 guru sekolah menengah atas yang tersebar di 8 sekolah kota komba dengan mengisi kuisioner secara lengkap. Teknik pengumpulan data dengan menggunakan Field Research. Data dianalisis dengan menggunakan Product Moment Pearson dan diperoleh $\mathrm{r}$ tabel dan nilai kofisien korelasi " $r$ " produk moment dengan derajat kebebasan $(\mathrm{df})=\mathrm{n}-2$ dan taraf nyata $(\alpha)=0,05$. Hasil penelitian diketahui $r$-hitung sebesar 0.456 , dan diketahui juga $r-$ tabel 0.413 pada tingkat signifikan 5\% $(0,05)$. Dengan demikian r-hitung $>$ r-tabel, $0.456>0,413$. Simpulan, terdapat pengaruh yang signifikan antara tingkat kesejahteraan guru komite terhadap semangat mengajar guru.
\end{abstract}

Kata Kunci: Kesejahteraan Guru, Semangat Mengajar

\begin{abstract}
This study aims to determine the effect of the welfare of committee teachers on the enthusiasm of teaching high school teachers in the Komba City sub-district, East Manggarai Regency, East Nusa Tenggara. This type of research is quantitative research that emphasizes the analysis of numerical data (numbers) obtained by statistical methods with the independent variable being the welfare of the teacher and the dependent variable is the spirit of teaching. The sample was 25 high school teachers spread in 8 city schools in Komba by completing the questionnaire in full. Data collection techniques using Field Research. Data were analyzed using Pearson Product Moment and obtained $r$ table and correlation coefficient of " $r$ " product moment with degrees of freedom $(d f)=n-2$ and real level $(\alpha)=0.05$. The results of this research are known $r$-count of 0.456 , and $r$ table of 0.413 is also known at a significant level of 5\% (0.05). Thus r-count> $r$ table, 0.456>0.413. Conclusion, there is a significant influence between the level of welfare of the committee of teachers on the enthusiasm of teaching teachers.
\end{abstract}

Keywords: Teacher Welfare, Spirit of Teaching 


\section{PENDAHULUAN}

Sebagai seorang pendidik, guru harus mampu menempatkan dirinya sebagai pengaruh dan pembina pengembangan bakat dengan kemampuan anak didik ke arah titik maksimal yang dapat mereka capai. Sedangkan menurut Sardiman (2007), pendidik adalah orang yang bertanggung jawab terhadap perkembangan anak dengan mengupayakan perkembangan seluruh potensi afeksi, kognitif, dan psikomotorik. Seorang guru yang bermutu juga harus mampu berperan sebagai pemimpin di antara kelompok siswanya dan juga di antara sesamanya, dia juga harus mampu berperan sebagai pendukung serta penyebar nilai-nilai luhur yang diyakininya, dan sekaligus sebagai teladan bagi siswa di lingkungan sosialnya

Ironisnya dalam profesi guru di Indonesia, yakni penghargaan terhadap profesi guru yang masih rendah terbukti dengan tidak meratanya kesejahteraan guru. Menurut pemikiran sekarang ini, bahwa semua orang termasuk pemerintah belum menyadari dan mempunyai komitmen untuk meningkatkan kesejahteraan dan mutu guru. Misalnya, dengan adanya diferensiasi guru oleh pemerintah. Ada guru PNS, guru honorer daerah, dan guru swasta (guru tidak tetap/guru komite). Pembedaan ini berimplikasi pada tingkat kesejahteraan guru yang intervalnya cukup jauh. Selain itu, untuk naik jabatan dan mengembangkan karir dipersulit dengan tuntutan yang adakalanya diada-adakan, semua kesalahan pendidikan ditimpahkan pada guru dan guru tidak pernah diperlakukan sebagai profesional dalam bidangnya, melainkan ibarat pegawai biasa. Secara formal, status guru di dalam masyarakat dan budaya Indonesia masih menempati tempat yang terhormat, namun secara material profesi guru mengalami kemerosotan yang menghawatirkan. Di mana-mana hampir di seluruh Indonesia penghargaan material terhadap guru sangat minim, bahkan sebagian besar guru berada di bawah garis kemiskinan.

Tampaknya pemerintah menempatkan peningkatan kesejahteraan guru dalam konteks kompetensi. Hal ini dapat dilihat dari beberapa indikataor. Pertama, pencanangan guru sebagai profesi oleh Presiden SBY pada tanggal 2 Desember 2004. Kedua, ditetapkannya UU No. 20 Tahun 2003 tentang Sistem Pendidikan Nasional. Ketiga, lahirnya PP No. 19 Tahun 2005 tentang Standar Nasional Pendidikan. Keempat, lahirnya UU No. 14 Tahun 2005 tentang Guru dan Dosen yang disahkan tanggal 6 Desember 2005. Undang-Undang ini juga mengangkat tiga aspek penting dalam peningkatan mutu pendidikan di Indonesia dilihat dari tenaga pendidik dan kependidikan, yakni kualifikasi, sertifikasi, dan kesejahteraan.

Berdasarkan data yang diperoleh dari setiap operator SMA Negeri SeKecamatan Kota Komba Kabupaten Manggarai Timur jumlah guru komite SMA Negeri Se-Kecamatan Kota Komba Kabupaten Manggarai Timur berjumlah 125 orang dengan perincian guru laki-laki berjumlah 75 orang dan guru perempuan 
berjumlah 50 orang, dengan kondisi gaji dan rentangan gaji yang terima dari setiap guru adalah sebagai berikut :

Tabel 1

Rentangan Gaji

\begin{tabular}{|c|c|c|c|c|c|c|c|}
\hline \multirow[t]{2}{*}{$\mathrm{NO}$} & \multirow{2}{*}{\multicolumn{4}{|c|}{ SEKOLAH }} & \multicolumn{2}{|c|}{ JUMLAH } & \multirow{2}{*}{$\begin{array}{c}\text { RENTANGAN } \\
\text { GAJI } \\
\end{array}$} \\
\hline & & & & & LAKI & PEREMPUAN & \\
\hline 1. & $\begin{array}{l}\text { SMA } \\
\text { Komba }\end{array}$ & Negeri & 1 & Kota & 7 & 5 & $500.000-1.050 .000$ \\
\hline 2. & $\begin{array}{l}\text { SMA } \\
\text { Komba }\end{array}$ & Negeri & 2 & Kota & 7 & 7 & $550.000-1.200 .000$ \\
\hline 3. & $\begin{array}{l}\text { SMA } \\
\text { Komba }\end{array}$ & Negeri & 3 & Kota & 7 & 9 & $350.000-650.000$ \\
\hline 4. & $\begin{array}{l}\text { SMA } \\
\text { Komba }\end{array}$ & Negeri & 4 & Kota & 8 & 6 & $300.000-600.000$ \\
\hline 5. & $\begin{array}{l}\text { SMA } \\
\text { Komba }\end{array}$ & Negeri & 5 & Kota & 13 & 5 & $500.000-750.000$ \\
\hline 6. & $\begin{array}{l}\text { SMA } \\
\text { Komba }\end{array}$ & Negeri & 6 & Kota & 12 & 8 & $400.000-800.000$ \\
\hline 7. & $\begin{array}{l}\text { SMA } \\
\text { Komba }\end{array}$ & Negeri & 7 & Kota & 10 & 5 & $350.000-600.000$ \\
\hline 8. & $\begin{array}{l}\text { SMA } \\
\text { Komba }\end{array}$ & Negeri & 8 & Kota & 9 & 7 & $300.000-500.000$ \\
\hline
\end{tabular}

Mengkaji dari data lapangan yang ada maka sangat terlihat bahwa kesejahteraan guru komite SMA Negeri Se-Kecamatan Kota Komb sangatlah rendah hal ini akan terlihat dari gaji yang diterima tidak lebih besar dari Upah Minimum Propinsi (UMP). Berdasarkan SK Gubernur NTT No 283/KEP/HK/2017 tentang UMP NTT 2018 menetapkan Upah Minimum Propinsi tahun 2018 sebesar Rp. 1.660.000. Untuk melakukan standarisasi gaji guru honorer minimal guru honorer harus digaji dengan standar Upah Minimum Propinsi(UMP). Motivasi guru merupakan faktor yang sangat penting dalam kinerja guru, dalam hal ini berkaitan dengan kesejahteraan, kondisi kerja, kesempatan untuk mengembangkan karir, dan pelayanan tambahan terhadap guru. Dan salah satu penentu semangat kerja guru adalah besar kecilnya imbalan dimana makin tinggi imbalan, makin tinggi kesungguhan, komitmen, dan produktivitas kerja serta makin kecil tindakan indisipliner.

\section{METODE PENELITIAN}

Jenis Penelitian yang digunakan adalah penelitian kuantitatif. Penelitian ini menekankan analisis pada data numerikal (angka) yang diperoleh dengan metode statistik Saifudin, (2001). Pendekatan yang digunakan dalam penelitian ini adalah: pendekatan deskritif kuantitatif 
Penelitian ini menggunakan dua macam instrumen (angket/qesioner dan dokumentasi). Angket/qesioner digunakan untuk memperoleh data berkaitan dengan Tingkat Kesejahteraan Guru (X) dan data Semangat Mengajar Guru (Y) yang akan disebarkan kepada responden penelitian.

Tabel 2

Kisi-Kisi Kesejahteraan Guru Komite Dan Semangat Mengajar Guru

\begin{tabular}{|c|c|c|c|}
\hline Variabel & Indikator & Nomor Butir & Jumlah \\
\hline \multirow{4}{*}{$\begin{array}{l}\text { Tingkat } \\
\text { Kesejahteraan Guru }\end{array}$} & $\begin{array}{l}\text { Tunjangan Gaji yang } \\
\text { Memadai }\end{array}$ & 1,2 & 2 \\
\hline & Insentif Uang Rapat & 3,4 & 2 \\
\hline & $\begin{array}{l}\text { Insentif Uang } \\
\text { Kegiatan }\end{array}$ & $5,6,7$ & 3 \\
\hline & Jaminan Sosial & $8,9,10$ & 3 \\
\hline \multirow{4}{*}{$\begin{array}{l}\text { Semangat Mengajar } \\
\text { Guru1“ }\end{array}$} & Disiplin masuk Kerja & $11,12,13$ & 3 \\
\hline & $\begin{array}{l}\text { Mengerjakan tugas } \\
\text { guru }\end{array}$ & $14,15,16,17,18,19$ & 6 \\
\hline & $\begin{array}{l}\text { Mengoreksi } \\
\text { pekerjaan siswa }\end{array}$ & 20,21 & 2 \\
\hline & $\begin{array}{l}\text { Mengembangkan } \\
\text { profesi guru dengan } \\
\text { membaca informasi } \\
\text { Pendidikan }\end{array}$ & $22,23,24$ & 3 \\
\hline
\end{tabular}

Butir

Tabel 3

Kisi-Kisi Kesejahteraan Guru Komite Dan Semangat Mengajar Guru

\begin{tabular}{|c|c|c|c|}
\hline Variabel & Indikator & Nomor Butir & Jumlah \\
\hline \multirow{4}{*}{ Tingkat Kesejahteraan Guru } & $\begin{array}{l}\text { Tunjangan Gaji } \\
\text { Yang Memadai }\end{array}$ & 1,2 & 2 \\
\hline & $\begin{array}{c}\text { Insentif Uang } \\
\text { Rapat }\end{array}$ & 3,4 & 2 \\
\hline & $\begin{array}{c}\text { Insentif Uang } \\
\text { Kegiatan }\end{array}$ & $5,6,7$ & 3 \\
\hline & Jaminan Sosial & $8,9,10$ & 3 \\
\hline \multirow[t]{4}{*}{ Semangat Mengajar Guru } & $\begin{array}{c}\text { Disiplin masuk } \\
\text { Kerja }\end{array}$ & $11,12,13$ & 3 \\
\hline & $\begin{array}{c}\text { Mengerjakan } \\
\text { tugas guru }\end{array}$ & $\begin{array}{c}14,15,16,17,18,1 \\
9\end{array}$ & 6 \\
\hline & $\begin{array}{c}\text { Mengoreksi pekerjaan } \\
\text { siswa }\end{array}$ & 20,21 & 2 \\
\hline & $\begin{array}{l}\text { Mengembangkan } \\
\text { profesi guru dengan } \\
\text { membaca informasi }\end{array}$ & $22,23,24$ & 3 \\
\hline
\end{tabular}


Pendidikan

Jumlah

24 Butir

Tabel 4

Kisi-Kisi Penilaian Angket

\begin{tabular}{cc}
\hline Jawaban & Skor/Nilai \\
\hline A & 4 \\
\hline B & 3 \\
\hline C & 2 \\
\hline D & 1 \\
\hline
\end{tabular}

Tabel 5

Kisi-Kisi Pedoman Dokumentasi

\begin{tabular}{|c|c|c|c|}
\hline \multirow[t]{2}{*}{$\overline{\text { No }}$} & \multirow[t]{2}{*}{ Aspek Yang Dibutuhkan } & \multicolumn{2}{|c|}{ Keterangan } \\
\hline & & Ada & Tidak ada \\
\hline 1. & $\begin{array}{l}\text { Keadaan Lokasi } \\
\text { Penelitian }\end{array}$ & Ada & \\
\hline \multirow{6}{*}{2.} & Administrasi Sekolah & & \\
\hline & $\begin{array}{l}\text { 1. SaranaPrasaran } \\
\mathrm{a}\end{array}$ & Ada & \\
\hline & $\begin{array}{ll}\text { 2. } & \text { Data Guru } \\
& \text { DanPegawai }\end{array}$ & Ada & \\
\hline & 3. DataSiswa & Ada & \\
\hline & $\begin{array}{ll}\text { 4. StrukturOrganis } \\
\text { asi }\end{array}$ & Ada & \\
\hline & 5. Visi DanMisi & Ada & \\
\hline
\end{tabular}

Dalam menganalisis data yang telah terkumpul dari penelitian yang bersifat kuantitatif peneliti menggunakan analisa data statistik dengan langkahlangkah sebagai berikut:

\section{Analisis Pendahuluan}

Dalam analisis ini akan disajikan data variabel Kesejahteraan Guru Komite dan variabel Semangat Mengajar Guru SMA Negeri Se- Kecamatan Kota Komba Kabupaten Manggarai Timur melalui data yang diperoleh dari responden melalui daftar angket. Setelah diketahui, data- data tersebut kemudian dimasukan kedalam tabel distribusi frekuensi untuk memudahkan perhitung untuk mengetahui tingkat masing-masing variabel dalam penelitian ini dan juga untuk mempermudah keterbacaan data yang ada dalam rangkah pengelolahan data selanjutnya. 


\section{Analisis Uji Hipotesis}

Analisis uji hipotesis ini merupakan jenis analisis yang bertujuan untuk menguji hipotesis yang diajukan oleh peneliti. Dalam hal ini Tingkat Kesejahteraan Guru merupakan Variabel X dan Semangat Mengajar Guru merupakan Variabel Y, maka untuk membuktikan kebenaran hipotesis yang diajukan akan menggunakan rumus Korelasi Pearson Product Moment (PPM). Adapun rumusnya sebagai berikut:

$$
r x y=\frac{N \sum x y-\left(\sum x\right)\left(\sum y\right)}{\sqrt{\left\{N \sum x^{2}-\left(\sum x\right)^{2}\right\}\left\{N \Sigma y^{2}-\left(\sum y\right)^{2}\right\}}}
$$

Keterangan

$$
\begin{array}{ll}
\text { rxy } & : \text { Koefisien } \\
\text { KorelasiProductMomentx } & : \text { Variabel KesejahteraanGuru } \\
\text { y } & : \text { Variabel Semangat MengajarGuru } \\
\mathrm{N} & : \text { JumlahSampel } \\
\Sigma & : \text { SigmaJumlah }
\end{array}
$$

Langkah-langkah uji korelasi Pearson Produk Moment sebagai berikut:

1. Membuat Ha dan Ho dengan bentuk kalimat

2. Membuat Ha dan Ho dalam bentuk statistik

3. Membuat tabel penolong untuk menghitung nilai korelasiPPM

4. Memasukan angka-angka statistik dari tabel penolong kedalam rumus PPM; dengan rumus sebagai berikut:

$$
r x y=\frac{N \sum x y-\left(\sum x\right)\left(\sum y\right)}{\sqrt{\left\{N \sum x^{2}-\left(\sum x\right)^{2}\right\}\left\{N \sum y^{2}-\left(\sum y\right)^{2}\right\}}}
$$

5. Menentukan besarnya sumbangan (koefisien deteminanatau koefisien penentu) variabel $\mathrm{X}$ terhadap variabel $\mathrm{Y}$ dengan mengunakan rumus sebagai berikut:

$$
K P=r^{2} X 100 \%
$$

6. Menguji signifikan dengan mengunakan rumus thitung.

Kaidah perngujian:

$$
t_{\text {hitung }}=\frac{r \sqrt{n-2}}{\sqrt{1-r^{2}}}
$$

Jika t hitung $>$ dari t tabel maka signifikan

Jika $t$ hitung $<$ dari $t$ tabel maka tidak signifikan

7. Kesimpulan 


\section{HASIL DAN PEMBAHASAN}

Setelah melakukan serangkaian penelitian dan berdasarkan hasil perhitungan analisis data maka ditemukan bebarapa hal sebagai berikut:Tingkat Kesejahteran Guru Komite SMA Negeri Se-Kecamatan Kota Komba Kabupaten Manggarai Timur yang dalam hasil analisis memperoleh nilai rata-rata 28.28 yang artinya setiap item pernyataan angket yang sebarkan memiliki nilai ratarata sebesar 28.28 dengan demikian nilai rata-rata ini menunjukan tingkat kesejahteraan guru komite masuk dalam kategori Sedang $(25.50$ - 32.25) dan ukuran kategori ini berdasarkan dari beberapa indikator yang telah ditentukan yaitu : Tunjangan Gaji Yang Memadai, Insentif Uang Rapat, Insentif Uang Kegiatan dan Jaminan Sosial.

Oleh karena itu kesejahteraan guru komite harus lebih serius diperhatikan karena kita ketahui tingkat kesejahteraan guru faktor penentu prestasi kerja guru yang mana guru hadir sebagai penentu paling besar terhadap prestasi belajar.Hal ini didukung dengan pernyataan Rusyan (2008:). Kesejahteran merupakan suatu tata kehidupan yang meliputi rasa aman, tentaram lahir dan batin serta terpenuhi kebutuhan hidup yang sebaiknya,

Semangat Mengajar Guru SMA Negeri Se-Kecamatan Kota Komba Kabupaten Manggarai Timur yang dalam hasil analisis memperoleh nilai ratarata 45.16 yang artinya setiap item pernyataan angket yang sebarkan memiliki nilai rata-rata sebesar 45.16 dengan demikian nilai rata-rata ini menunjukan semangat mengajar guru komite masuk dalam kategori Sedang $(35.50$ - 45.25) ukuran kategori ini berdasarkab beberapa indikator yang telah ditentukan yaitu : Disiplin Masuk Kerja, Mengerjakan Tugas-Tugas Guru, Mengoreksi Pekerjaan Siswa dan Mengembangkan Profesi Guru Dengan Membaca Informasi Pendidikan.

Dari nilai rata-rata dapat dilihat bahwa ada pengaruh dari faktor lain yang membuat membuat semangat mengajar guru menurun. Menurut Supriadi (2007) mengatakan bahwa pekerja dengan semangat menjalankan suatu pekerjaan tergantung dari besar kecilnya imbalan. Yang artinya bahwa orang akan semangat dalam bekerja atau dalam hal ini guru akan semangat dalam mengajar apabila kesejahteraan guru tersebut memadai sehingga guru dapat meningkatkan proses kegiatan belajar mengajar dengan baik tanpa harus memikirkan beban hidup yang belum terpenuhi.

Kosasi (2009) menjelaskan semangat mengajar bukan hanya berkaitan dengan kemauan untuk mengajar atau menyampaikan materi kepada siswa saja melainkan suatu bentuk sikap dan tanggungjawab yang meliputi sikap loyalitas dalam kerja, sikap disiplin dan juga mampuh bertanggungjawab dalam menjalankan tugas-tugas guru.

Berdasarkan hasil perhitungan korelasi Pearson Product Moment diperoleh nilai rxy $=0.456$ kemudian dihitungan besar sumbangan (kontribusi) variabel X terhadap variabel $\mathrm{Y}$ maka dapat peroleh nilai sebesar $20.79 \%$. 
Selanjutnya berdasarkan hasil perhitungan Uji t maka diperoleh nilai t hitung = 2.457 dannilaittabelpadatarafsignifikan5\%(0.05) diperoleh nilai sebesar2.069 dengan demikian $\mathrm{t}$ hitung $>\mathrm{t}$ tabel atau $2.457>2.069$; maka hal ini berarti tingkat kesejahteran guru komite mempunyai korelasi yang signifikan terhadap semangat mengajar.

Dari hasil perhitungan Pearson Product Moment (PPM) maka telah diperoleh nilai rxy $=0.456$ dikonsultasi dengan tabel $r$ Product Moment diketahui juga "r"Tabel 0.413 tingkat signifikan $5 \%(0,05)$. Dengan kata lain $\mathrm{Ro}=0,456>$ dari $\mathrm{Rt}=0.413$. Dengan demikian ini menunjukan bahwa ada pengaruh yang signifikan antara Tingkat Kesejahteraan Guru Komite Terhadap Semangat Mengajar.

\section{SIMPULAN}

Berdasakan hasil penelitian ini dapat disimpulkan bahwa berdasarkan hasil Analisis maka diketahui " $r$ "Observasi sebesar 0.456, dan diketahui juga " $r$ " Tabel 0.413 pada tingkat signifikan $5 \%(0,05)$. Dengan kata lain Ro $=0.456>$ dari Rt $=0.413$. Dengan demikian berarti bahwa hipotesis yang berbunyi terdapat pengaruh yang signifikan antara Tingkat Kesejahteraan Guru Komite Terhadap Semangat Mengajar Guru SMA Negeri Se-Kecamatan Kota Komba Kabupaten Manggarai Timur dapat diterima atau dengan kata lain bahwa menolak Ho (Hipotesis Nihil) dan menerima Ha (Hipotesis Alternatif). Dengan demikian tingkat kesejahteraan guru berpengaruh terhadap semangat mengajar pada derajat kepercayaan $20.79 \%$ sedangkan sisanya sebesar $79.21 \%$ merupakan variabel lain yang belum diteliti oleh peneliti lainnya. 


\section{DAFTAR PUSTAKA}

Azwar, S. (2001). Metode Penelitian. Yogyakarta: Pustaka Pelajar.

Rusyam.(2008). Kapan Guru Sejahtera. Yogyakarta: Bigraf.

Sardiman.(2007). Interaksi dan Motivasi Belajar Mengajar. Jakarta: PT Raja Grafindo Persada.

Soetjipto \& Raflis, K.(2009). Profesi Keguruan.Jakarta: Rineka Cipta. Sugiyono.(2009). Metode Penelitian Pendidikkan.Bandung: Alfabeta.

Supriadi, D. (2007). Mengangkat Citra dan Martabat Guru. Yogyakarta: Adicita Karya Nusa.

Suworna. (2006). Pandangan Pendidikan Masa Depan. Yogyakarta: Bigraf. M, Salim. (2005). Kesejahteran Dalam Pendidikan. Bandung: Alfabeta. 